\title{
Medical genomics at the Systems Biology and Bioinformatics (SBB-2019) school
}

\author{
Yuriy L. Orlov ${ }^{1,2,3^{*}}$, Elena N. Voropaeva ${ }^{3}$, Ming Chen ${ }^{4}$ and Ancha V. Baranova ${ }^{5,6}$ \\ From 11th International Young Scientists School "Systems Biology and Bioinformatics" - SBB-2019 \\ Novosibirsk, Russia. 24-28 June 2019
}

Next-Generation Sequencing-driven analysis and Systems Biology approaches commonly serve as a backdrop for a study of a tumor genome. This issue of BMC Medical Genomics SBB-2019 ("Systems Biology and Bioinformatics") presents recent works discussed at the 11th Young Scientists School "Systems Biology and Bioinformatics"-2019, held in Novosibirsk, Russia (http://conf.bionet.nsc.ru/sbb2 019/en/). Here we collated some cancer gene expression studies, some mutation profiling studies as well as some insightful case reports. The SBB school series on bioinformatics proceeds annually since 2008 under the joint steerage of the Institute of Cytology and Genetics of the Siberian Branch of the Russian Academy of Sciences and Novosibirsk State University [1, 2]. We had publications in special topic issues after the Schools before in BMC Genomics, BMC Medical Genomics and related BioMed Central family journals since 2014 [3-5]. The SBB Schools in Novosibirsk were initially conceived as satellite event for young scientists held at the same time as BGRSISB (Bioinformatics of Genome Regulation and Structure \Systems Biology) conference series, since 1998 taking place biannually. The recent BGRSISB-2020 event in Novosibirsk was over at the time of the current journal issue publication (https://bgrssb.icgbio.ru/2020/). Other special issues (Supplements) to the BMC journals in the fields of genomics, genetics, bioinformatics, and medical genetics are published at BMC Genomics, BMC Genetics and three other BMC journals. The BGRS\SB-2018 conference highlights were published in 2018 [5-7], and continued the BMC Medical

\footnotetext{
* Correspondence: orlov@d-health.institute

${ }^{1}$ The Digital Health Institute, I.M.Sechenov First Moscow State Medical

University (Sechenov University), 119991 Moscow, Russia

${ }^{2}$ Novosibirsk State University, 630090 Novosibirsk, Russia

Full list of author information is available at the end of the article
}

Genomics special issues in 2019 [8]. Public discussion of the conference presentations at the open access platforms of BioMed Central and other publishers serve as an international educational resource for young scientists $[9,10]$.

The articles comprising this issue of BMC Medical Genomics are focused on cancer genomics. Using transcriptomic data, bioinformatic models can be built for patientoriented ranking of cancer drugs [11]. Nicolas Borisov et al. [12] (this issue) developed the database for cancer gene expression profiles associated with clinical outcomes of the chemotherapy treatments. Authors mined Gene Expression Omnibus (GEO), The Cancer Genome Atlas (TCGA) and Tumor Alterations Relevant for GEnomicsdriven Therapy (TARGET) repositories to pull a database of 2786 gene expression profiles associated with clinical responses on chemotherapy. The cases represented breast cancer, lung cancer, low-grade glioma, endothelial carcinoma, multiple myeloma, adult leukemia, pediatric leukemia and kidney tumors and suitable for Machine Learning analysis of these malignancy.

Alexander Lavrov and co-authors [13] (this issue) review pathogenic variants targetable by single base editing. Single nucleotide variants account for approximately $90 \%$ of all known pathogenic variants responsible for human diseases, including thousands of known 6000 monogenic diseases. Recently discovered CRISPR/Cas9 base editors are capable of correcting individual nucleotide positions, thus, providing opportunities for personalized therapy. Unfortunately, none of such editors are perfect in their specificity [14]. Authors summarized all possible pathogenic variants which may be efficiently targeted by each of the known base editors. They analyzed 21 editing system currently reported in 9 publications and showed that $\mathrm{C}>\mathrm{T}$ base editors are capable of precisely targeting about 3200 mutations, a total of 
$46 \%$ of all pathogenic $\mathrm{T}>\mathrm{C}$ variants, while $\mathrm{A}>\mathrm{G}$ editors may precisely target 6900 mutations (34\% of all pathogenic $\mathrm{G}>\mathrm{A}$ variants). Thus, even now the list of mutations which can be targeted with currently available systems is very large, and enough to choose from and embrak on developing new targeted therapies.

Next few papers highlight genomic studies of particular tumors. Anna Kudryavtseva et al. [15] (this issue) discuss mutation profiles of vagal paragangliomas, a group of rare head and neck neuroendocrine tumors, arising from the vagus nerve, and differing from more common carotid paragangliomas dissected by same group of authors earlier $[16,17]$. Authors collected vagal paragangliomas from 8 patients, analyzed tumor exomes and discussed their findings in details. In particular, a number of novel and known pathogenic/likely pathogenic variants of the SDHx genes, frequently mutated in paragangliomas/pheochromocytomas were described.

Elena Pudova and colleagues [18] (this issue) analyzed miRNAs expression signatures associated with lymphatic dissemination of the locally advanced prostate tumors. Making an informed decision on PC treatment options after radical prostatectomy (with expanded pelvic lymphadenectomy) is far from being easy and depends on the stratification of patients into risk groups according to tumor stage, Gleason index, PSA level, and regional metastasis. These clinical indicators are clearly in the need of augmenting with some molecular biomarkers. The changes in miRNA expression profiles associated with lymphatic dissemination of the prostate cancer yielded a couple of miRNAs suitable for the development into the prognostic tools. The most prominent condidates, namely, miR-20a-5p, miR-106a-5p, miR-93-5p, and miR-15b$5 \mathrm{p}$ are well-known players in oncogenic transformation or tumor suppression [19].

Tatyana Vasilyeva et al. [20] (this issue) present a case study of congenital aniridia caused by pericentric inversion in the chromosome 11. Aniridia is a Mendelian autosomal dominant developmental disorder that can affect all eye structures as well as central nervous system, the endocrine system, and other systems and organs. In the case described, a near-megabase deletion removed a locus with ELP4, PAX6, and RCN1 genes while the coding sequence of the WT1 gene was not affected. The authors conclude that the risk of developing Wilms' tumor in a probed is similar to that in the general population.

We conclude this special journal issue by the multiple paraganglioma cases report compiled by Vladislav Pavlov et al. [21] (this issue). The authors report a case of multiple paragangliomas, manifesting as bilateral carotid and vagal paragangliomas. After immunostaining for succinate dehydrogenase (SDH) subunits and exome analysis, a likely pathogenic variant in the SDHD gene was found in the germline, with additional likely pathogenic somatic variants founds in some of the tumors. It seems that authors sussessfully pinpointed germline variant in the SDHD gene as a driver of the development of multiple paragangliomas.

Overall, this issue includes reports of recent medical genomics applications in cancer and databases development, as well as case reports, continuing series on BMC Med Genomics special post-conference journal issues $[10,17,22$, 23]. We hope for continuing international exchange and education via the schools and competitions for young scientists. We invite our readers worldwide to attend the systems biology meetings in Russia. Digital Medicine Forum (Digital Medicine Forum) and MGNGS-2020 (Medical Genetics - Next-Generation Sequencing) event postponed to 2021 (http://ngs.med-gen.ru/mgngs20/).

\section{Acknowledgments}

We are grateful to Professor Academician N.A. Kolchanov for the organization of the "Systems Biology and Bioinformatics"-2019 event and providing platform for international bioinformatics and genomics research. We acknowledge Prof. T.V. Tatarinova for the editorial work on SBB-2019 issues and the organization of the "Centenary of Human Population Genetics" conference in Moscow in 2019 that provided materials to the SBB-2019 special issue series at BioMed Central journals. Thanks to Prof. R.A.Zinchenko and Dr. M.Y.Skoblov for MGNGS-2019 conference organization.

SBB-19 School holding in Novosibirsk was supported by RFBR (grant 19-0420036). YO (medical genetics study) was supported by RSF (grant 19-1500219).

The guest editors of the special issue are grateful to the conference committee members and the reviewers who helped in the peer-review and the special issue preparation. We acknowledge Mikhail Ponomarenko (Institute of Cytology and Genetics SB RAS, Novosibirsk, Russia), Hildegard Nikki Hall (University of Edinburgh, UK), Olga Arkova (Institute of Gene Biology RAS, Moscow), Piramanayagam Shanmughavel (Bharatiar University, India), Haiqing Zhao (Columbia University Medical Center, USA), Vitaly Gursky (S.Petersburg Polytech University, Russia), Olga Zolotareva (Bielefeld University, Germany), Elvira Galieva (Novosibirsk State University, Russia), Alexey Kolodkin (University of Luxemburg), Alexander Ratushny (Bristol Myers Squibb, USA), Eric Mjolsness (Irvine University, USA), Paul Jones (AIC Inc., USA), Shuan Li (University of Rhode Island, USA), Mengting Liu (University of Southern California, USA), Lydia Manor (AIC Inc., USA), Guohao Wang (NIH, USA), Nina Oparina (Karolinska Institut, Sweden), Stanislav Rybtsov (University of Edinburgh, UK), Anastasia Efimenko (Moscow State University, Russia), Ed Hollox (University of Leicester, USA), Igor Sharakhov (Virginia Tech, USA), Alexander Konev (NRC «Kurchatov Institute» - PNPI, Gatchina, Russia), Anatoly Ivashchenko (al-Farabi Kazakh National University, Kazakhstan), Ekaterina Marakasova (US FDA, USA), Chris Tyler (Sanger Centre, UK), Dmitry Karpov (Institute of Biomedical Chemistry RAS), Nikolai Barlev (Institute of Cytology RAS, St.-Petersburg, Russia), Elena Leberfarb (Novosibirsk State Medical University,

Russia), Lyubov Chuvakova (Moscow State University, Russia), Andrei Krivtsov (Dana Farber Cancer Institute, USA), Olga Tarasova (Sechenov University, Moscow, Russia), Nadezhda Antipova (Moscow State University, Russia), Oleg Gusev (RIKEN, Japan), Konstantin Gunbin (Novosibirsk State University, Russia), Hua Zhong (Fred Hutchinson Cancer Research Center, USA), Elena Zaklyazminskaya (Petrovsky Russian Research Centre of Surgery, Russia), Nataly Bondar (Novosibirsk State University, Russia), Michael Linderman (Icahn School of Medicine at Mount Sinai), Sergei Fedotov (MEPhl, Moscow, Russia), Vadim Efimov (Novosibirsk State University, Russia), Gordon Crippen (University of Michigan, USA), Igor Berezovsky (Bioinformatics Institute, Singapore), Andreas Laner (Medizinisch Genetisches Zentrum, Munich, Germany), Arun Kumar (Shanmugha Arts Science Technology and Research Academy, India), Lars Fehren-Schmitz (University of California Santa Cruz, USA), Mikhail Sadovsky (Siberian Federal University, Krasnoyarsk, Russia), Nataliya Dorogova (Institute of Cytology and Genetics SB RAS, Novosibirsk, Russia), Vasily Ramensky (National Research Institute of Preventive Medicine, Moscow, Russia), Patrick Harrison (University College Cork, Ireland), Irina Medvedeva (Bristol Myers Squibb, USA). 


\section{About this supplement}

This article has been published as part of BMC Medical Genomics Volume 13 Supplement 8, 2020: Selected Topics in "Systems Biology and Bioinformatics" 2019: medical genomics. The full contents of the supplement are available online at https://bmcmedgenomics.biomedcentral.com/articles/supplements/ volume-13-supplement-8.

\section{Authors' contributions}

$A B$ and $Y O$ are guest editors of the special post-conference issues and Program Committee members of SBB-2019 School. EV and MC are the invited editor and the organizing committee member of the conference. All the authors read, revised, and approved the final manuscript.

\section{Funding}

Publication of this article was not covered by sponsorship.

\section{Competing interests}

The authors declare that they have no competing interests.

\section{Author details}

${ }^{1}$ The Digital Health Institute, I.M.Sechenov First Moscow State Medical University (Sechenov University), 119991 Moscow, Russia. ${ }^{2}$ Novosibirsk State University, 630090 Novosibirsk, Russia. ${ }^{3}$ Research Institute of Internal and Preventive Medicine - Branch of the Institute of Cytology and Genetics SB RAS, 630089 Novosibirsk, Russia. ${ }^{4}$ Department of Bioinformatics, College of Life Sciences, First Affiliated Hospital of Medical School, Zhejiang University, Hangzhou 310058, China. ${ }^{5}$ George Mason University, Fairfax, VA 22030, USA.

${ }^{6}$ Research Centre for Medical Genetics, 115522 Moscow, Russia.

\section{Published: 18 September 2020}

\section{References}

1. Baranova AV, Orlov YL. The papers presented at 7th Young Scientists School "Systems Biology and Bioinformatics" (SBB'15): Introductory Note. BMC Genet. 2016;17:S20. https://doi.org/10.1186/s12863-015-0326-5.

2. Orlov $Y L$, Kolchanov NA, Hofestädt R, Wong L. Editorial - bioinformatics development at the BGRS $\backslash S B$ conference series: 10th anniversary. J Bioinforma Comput Biol. 2017;15(2):1702001. https://doi.org/10.1142/ S0219720017020012.

3. Orlov YL, Baranova AV, Markel AL. Computational models in genetics at BGRSISB-2016: introductory note. BMC Genet. 2016;17(Suppl 3):155. https:// doi.org/10.1186/s12863-016-0465-3.

4. Orlov YL, Baranova AV, Hofestaedt R, Kolchanov A. Computational genomics at BGRS\SB-2016: introductory note. BMC Genomics. 2016;17(Suppl 14):996. https://doi.org/10.1186/s12864-016-3350-6.

5. Orlov YL, Fernandez-Masso JR, Chen M, Baranova AV. Medical genomics at Belyaev conference - 2017. BMC Med Genet. 2018;11(Suppl 1):11. https:// doi.org/10.1186/s12920-018-0324-3.

6. Tatarinova TV, Chen M, Orlov YL. Bioinformatics research at BGRS-2018. BMC Bioinform. 2019;20:33. https://doi.org/10.1186/s12859-018-2566-7.

7. Orlov YL, Baranova AV. Editorial: bioinformatics of genome regulation and systems biology. Front Genet. 2020;11:625. https://doi.org/10.3389/fgene. 2020.00625.

8. Orlov YL, Galieva ER, Melerzanov AV. Computer genomics research at the bioinformatics conference series in Novosibirsk. BMC Genomics. 2019; 20(Suppl 7):537. https://doi.org/10.1186/s12864-019-5846-3.

9. Baranova AV, Klimontov W, Letyagin AY, Orlov YL. Medical genomics research at BGRS-2018. BMC Med Genet. 2019;12(Suppl 2):36. https://doi. org/10.1186/s12920-019-0480-0.

10. Voropaeva EN, Pospelova TI, Voevoda MI, Maksimov VN, Orlov YL, Seregina OB. Clinical aspects of TP53 gene inactivation in Diffuse Large B-cell Lymphoma. BMC Med Genomics. 2019;12(Suppl 2):35. https://doi.org/10. 1186/s12920-019-0484-9.

11. Borisov N, Shabalina I, Tkachev V, Sorokin M, Garazha A, Pulin A, Eremin II, Buzdin A. Shambhala: a platform-agnostic data harmonizer for gene expression data. BMC Bioinform. 2019;20(1):66. https://doi.org/10.1186/ s12859-019-2641-8.

12. Borisov N, Sorokin M, Tkachev V, Garazha A, Buzdin A. Cancer gene expression profiles associated with clinical outcomes to chemotherapy treatments. BMC Med Genomics. 2020;13(Suppl 8) https://doi.org/10.1186/ s12920-020-00759-0.
13. Lavrov AV, Varenikov GG, Skoblov MY. Genome scale analysis of pathogenic variants targetable for single base editing. BMC Med Genomics. 2020; 13(Suppl 8) https://doi.org/10.1186/s12960-020-00735-8.

14. Li X, Wang Y, Liu Y, Yang B, Wang X, Wei J, et al. Base editing with a Cpf1cytidine deaminase fusion. Nat Biotechnol. 2018;36(4):324-7. https://doi.org/ 10.1038/nbt.4102

15. Kudryavtseva AV, Kalinin DV, Pavlov VS, Savvateeva MV, Fedorova MS, Pudova EA, Kobelyatskaya AA, Golovyuk AL, Guvatova ZG, Razmakhaev GS, Demidova TB, Simanovsky SA, Slavnova EN, Poloznikov AA, Polyakov AP, Melnikova NV, Dmitriev AA, Krasnov GS, Snezhkina AV. Mutation profiling in eight cases of vagal paragangliomas. BMC Med Genomics. 2020;13(Suppl 8) https://doi.org/10.1186/s12960-020-00763-4.

16. Snezhkina AV, Lukyanova EN, Kalinin DV, Pokrovsky AV, Dmitriev AA, Koroban NV, Pudova EA, Fedorova MS, Volchenko NN, Stepanov OA, Zhevelyuk EA, Kharitonov SL, Lipatova AV, Abramov IS, Golovyuk AV, Yegorov YE, Vishnyakova KS, Moskalev AA, Krasnov GS, Melnikova NV, Shcherbo DS, Kiseleva MV, Kaprin AD, Alekseev BY, Zaretsky AR, Kudryavtseva AV. Exome analysis of carotid body tumor. BMC Med Genet. 2018;11(Suppl 1):17. https://doi.org/10.1186/s12920-018-0327-0.

17. Kudryavtseva AV, Lukyanova EN, Kalinin DV, Zaretsky AR, Pokrovsky AV, Golovyuk AL, Fedorova MS, Pudova EA, Kharitonov SL, Pavlov VS, Kobelyatskaya AA, Melnikova NV, Dmitriev AA, Polyakov AP, Alekseev BY, Kiseleva MV, Kaprin AD, Krasnov GS, Snezhkina AV. Mutational load in carotid body tumor. BMC Med Genet. 2019;12(Suppl 2):39. https://doi.org/ 10.1186/s12920-019-0483-x

18. Pudova EA, Krasnov GS, Nyushko KM, Kobelyatskaya AA, Savvateeva MV Guvatova ZG, Poloznikov AA, Dolotkazin DR, Klimina KM, Melnikova NV, Dmitriev AA, Kaprin AD, Alekseev BY, Snezhkina AV, Kudryavtseva AV. miRNAs expression signature potentially associated with lymphatic dissemination in locally advanced prostate cancer. BMC Med Genomics. 2020;13(Suppl 8). https://doi.org/10.1186/s12920-020-00763-4.

19. Chen Y, Chen J, Liu Y, Li S, Huang P. Plasma miR-15b-5p, miR-338-5p, and miR-764 as Biomarkers for Hepatocellular Carcinoma. Med Sci Monit. 2015; 21:1864-71. https://doi.org/10.12659/MSM.893082.

20. Vasilyeva TA, Marakhonov AV, Minzhenkova ME, Markova ZG, Petrova NV, Sukhanova NV, Koshkin P, Pyankov D, Kanivets IV, Korostelev SA, Krynskaya IA, Shilova NV, Kutsev SI, Kadyshev W, Zinchenko RA. A sporadic case of congenital aniridia caused by pericentric inversion inv (11)(p13q14) associated with a $977 \mathrm{~kb}$ deletion in the 11 p13 region. BMC Med Genomics. 2020;13(Suppl 8). https://doi.org/10.1186/s12920-020-00790-1.

21. Pavlov VS, Kalinin DV, Lukyanova EN, Golovyuk AL, Fedorova MS, Pudova EA, Savvateeva MV, Lipatova AV, Guvatova ZG, Kaprin AD, Kiseleva MV, Demidova TB, Simanovsky SA, Melnikova NV, Dmitriev AA, Krasnov GS, Snezhkina AV, Kudryavtseva AV. Multiple paragangliomas: a case report. BMC Med Genomics. 2020;13(Suppl 8). https://doi.org/10.1186/s12920-020-00789-8.

22. Saik OV, Nimaev W, Usmonov DB, Demenkov PS, Ivanisenko TV, Lavrik IN, Ivanisenko VA. Prioritization of genes involved in endothelial cell apoptosis by their implication in lymphedema using an analysis of associative gene networks with ANDSystem. BMC Med Genet. 2019;12(Suppl 2):47. https:// doi.org/10.1186/s12920-019-0492-9.

23. Sparber P, Filatova A, Khantemirova M, Skoblov M. The role of long noncoding RNAs in the pathogenesis of hereditary diseases. BMC Med Genet. 2019;12(Suppl 2):42. https://doi.org/10.1186/s12920-019-0487-6.

\section{Publisher's Note}

Springer Nature remains neutral with regard to jurisdictional claims in published maps and institutional affiliations.

\section{Ready to submit your research? Choose BMC and benefit from:}

- fast, convenient online submission

- thorough peer review by experienced researchers in your field

- rapid publication on acceptance

- support for research data, including large and complex data types

- gold Open Access which fosters wider collaboration and increased citations

- maximum visibility for your research: over $100 \mathrm{M}$ website views per year

At $\mathrm{BMC}$, research is always in progress.

Learn more biomedcentral.com/submissions 